\title{
Application Savonius Turbine on Ferries 750 GT
}

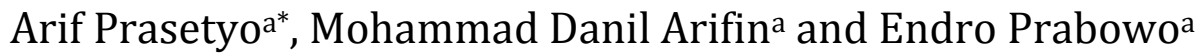 \\ a Faculty of Marine Technology, Darma Persada University (UNSADA), Jakarta, Indonesia
}

\begin{abstract}
Vessel operating costs the highest for purchase of fuel, with the increasingly limited oil reserves and the trend of oil price increases every year this is will add to the high operating costs. Important to start doing research for deploying renewable energy on the ship, especially to reduce the use of auxiliary engine on the ship. For renewable energy applications on ships using wind energy is available throughout the day. Application on the ship using savonius turbine, with high rotor $50 \mathrm{~cm}$, diameters $40 \mathrm{~cm}$, use of gear ratio to increase the rotation of the rotor and the generator $200 \mathrm{~W}$.

Assuming when a sail the wind speed $12 \mathrm{~m} / \mathrm{s}$ and the results of the electricity generated by the generator is average of $100 \mathrm{Wh}$. With the early stages of the installation 20 units turbines, then the results el ectricity generated can reach $2.000 \mathrm{~W} \times 24 \mathrm{~h}=4.8 \mathrm{kWh} / \mathrm{d}$. This is certainly a very promising result for future development. With continuously research can certainly achieve the best efficiency.
\end{abstract}

Keywords: Renewable energy, Ship, Savonius turbine, Wind energy

\section{Introduction}

All engine manufacturers continue to innovate to create a more efficient engine in use of fuel. The results created dual fuel engine, mixing between the gas and fuel to the combustion chamber and the use of turbo charger. But still the results of these optimizations are only partially transformed into mechanical energy to work and the rest is waste to be heat.

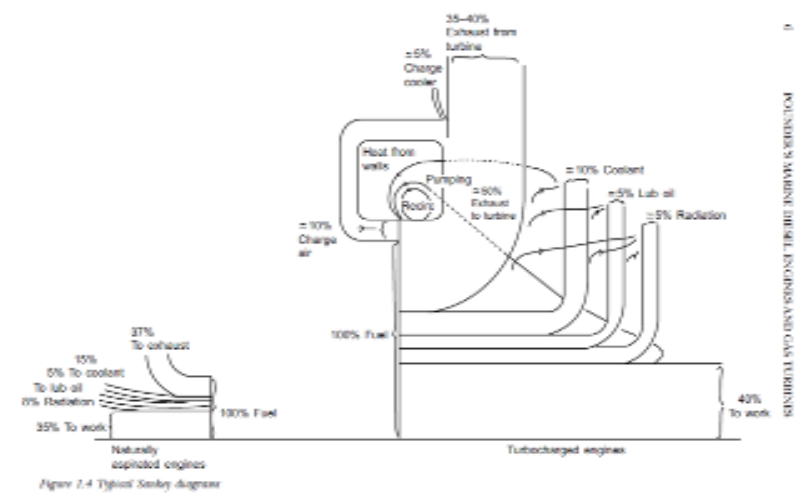

Fig. 1 Typical Sankey Diagrams

* Corresponding Author. Tel : + 6285711772228

E-mail: arifp1215@yahoo.com / arifp1215@hotmail.com
Therefore it is important to begin find alternative energy, renewable energy where energy use is only limited as auxiliary and not be the main propulsion. Where this has been started by a few countries, such as German with sky sails are used to pull container ships where there is fuel savings of $35 \%$ of course this is a promising result for development in a future.

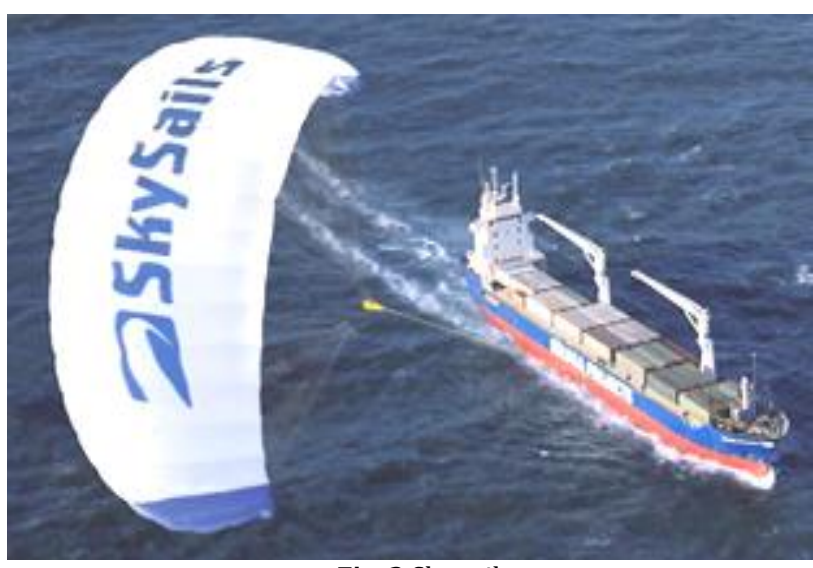

Fig. 2 Sky sails

With the presence of concept ship Wallenius Wilhelmsen which ready for launch in 2025 in which almost of all the energy that is around the ship can use, such as wind, solar, wave energy, fuel cells and 
hydrogen, important to participate development of renewable energy that can be applied to the ship. With the application of the savonius turbine in ship ferry 750 GT, which aplicated on the top deck area of the ship, why in a top deck, because there is no passing people so it is safe to be applied and also the availability of vast space on the top deck so it can be aplicated in large amounts, so that can create a wind farm and electricity can produced be maximal, would direct impact on reducing workload of the auxiliary engine.

\section{Material and Method}

Here is a main data of the ferry 750 GT which will be applied savonius turbine, dimensions and size of the vessel are:

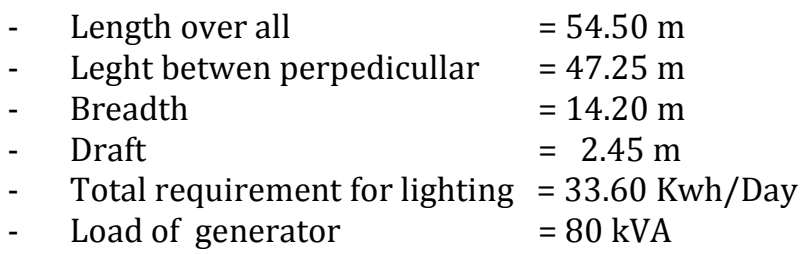

\subsection{Overview of Installation on Ships}

- $\quad$ Ship Design

Design space on the ship is very calculated due to influent with the cost of manufacture of the vessel, so we must selected of renewable energy that will be applied the result must be maximum.

- $\quad$ Scope of Usage

Because the ship sailing at the sea, so that renewable energy equipment that will be applied must be resistant corrosion caused by sea water "Marine Use".

- $\quad$ Ship Resistance

On the ship there air resistance (RA), as this will affect to the ships resistance when sailing, so that renewable energy will be applied to the ship should be as minimum as possible provide resistance on the ship.

\section{- Stability}

The most important factor of a ship is a stabilit, as it will affect the safety and comfort while cruising, so that renewable energy be applicated to the ship should be not decrease stability of the ship.

\section{- $\quad$ Safety}

Safety factor is very important, for the ship and crew that operate and must not interfere operation of the ship.

Based on the description can be concluded to find renewable energy can work on a ship without disrupting the performance of the vessel and must be able to work all day, because it is based on the design of the ship that will be changed and the investment costs for the installation savonius turbines, so that its benefits can be felt very well.

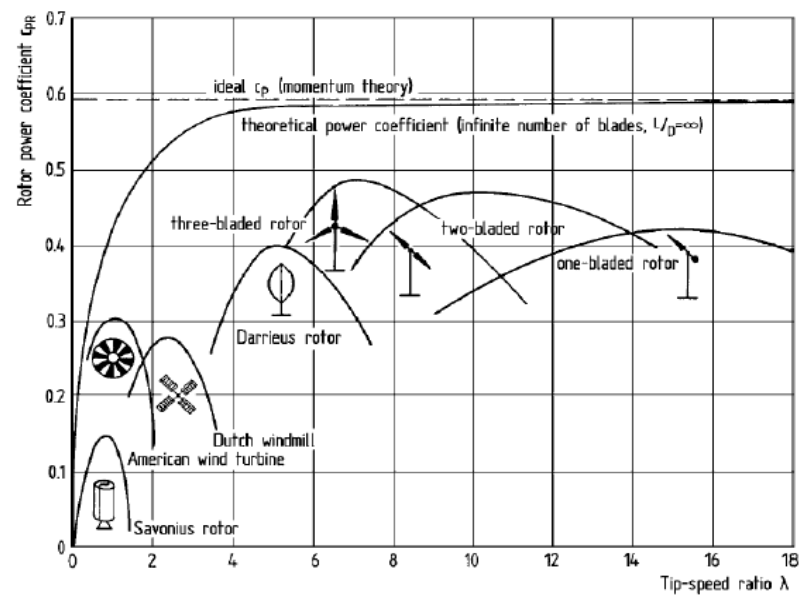

Fig. 3 Results of various types of turbine

From the above table, savonius turbine chosen for several reasons :

- The design is simple, can handle wind turbulence with good and simple blade shape.

- $\quad$ Do not have the turning radius to drive to the wind direction, so it can get wind from all direction.

- Design savonius which can rotate at very low wind speeds up to high.

\subsection{Planning Instalation Savonius Turbine}

Power generated by the rotor savonius will next be transmitted to the generator. The electricity generated will be used to help the lighting system on the ship. This is a scheme application savonius turbine on ship. 


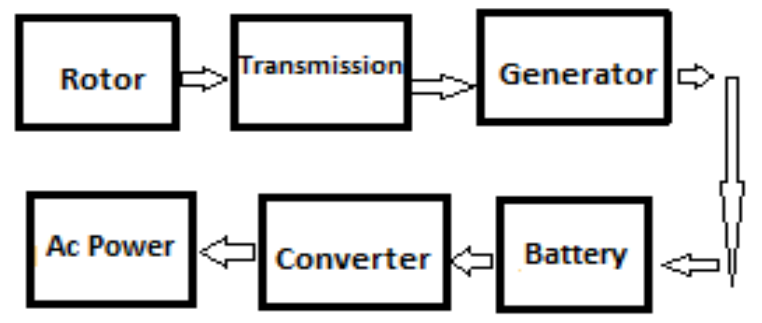

a. Rotor Calculations

$P_{\max }=0.18 \cdot H \cdot D \cdot v^{3}[W]$

b. Transmission

Diameter rotor gear $\quad: 18 \mathrm{~cm}$

Diameter generator gear $\quad: 7 \mathrm{~cm}$

c. Generator

Phase : 3 phase

Out Max : 200 watt

Rpm : : $150-3000$ Rpm

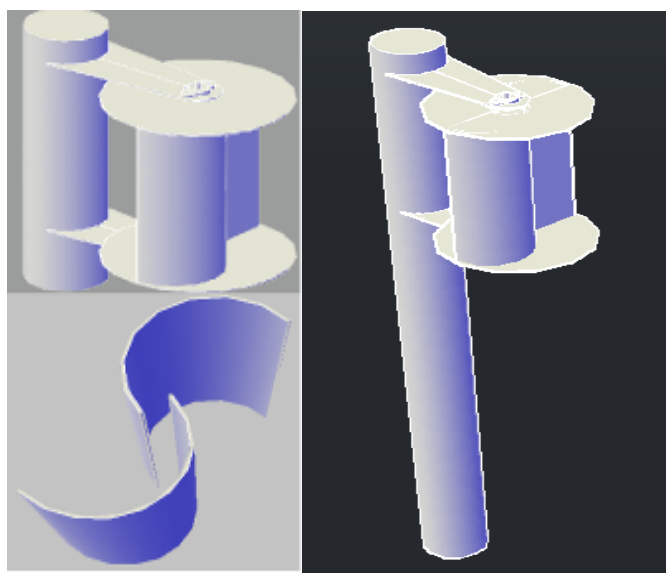

Fig. 4 Savonius turbine design

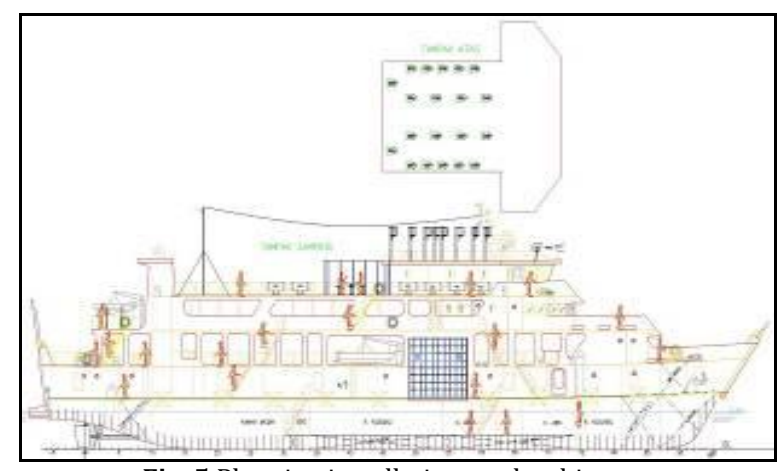

Fig. 5 Planning installation on the ship.

\section{Result and Discussion}

The result of making the actual size, Blade is made using PVC with rotor height $50 \mathrm{~cm}$, diameter $40 \mathrm{~cm}$. Results of testing with wind speed of $9 \mathrm{~m} / \mathrm{s}$ obtained rotor speed $240 \mathrm{rpm}$, then the rotation of the rotor is transmitted using a gear ratio to increase the round with ratio 1: 2.5 so it will increase the rotation of the rotor.

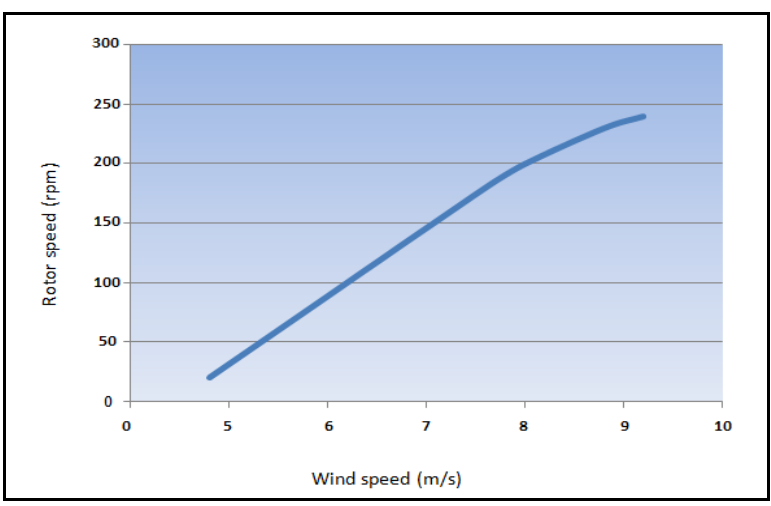

Fig. 6 Windspeed versus rotor speed.

And then performed experiments with the use of generators, rotor speed $180 \mathrm{rpm}$, voltage $12 \mathrm{~V}$ and current 1.1 A. Decrease in rotor speed due to the use of the transmission and the torque of the generator is increased when given load. Resulting electrical current generated is not maximized due to rotor rotation of generator must be $3000 \mathrm{RPM}$ to produce $200 \mathrm{~W}$. But in the future with the use of a special generator for wind power, with power $200 \mathrm{~W}$ only takes $400 \mathrm{RPM}$, this of course will make the results is according to plans.

Electricity generated will be used to aid light the lamp on the ship be expected to reduce the use of auxiliary engines. With fluctuating speeds of course the result will be different when the ship was sailing and lie at anchor. With a maximum output of generator $200 \mathrm{~W}$ but with different wind speeds, it is assumed that electricity produced averaged $100 \mathrm{~W}$, with existing wind for 24 hours. The turbine needs to calculation the power requirements for lighting power $33.60 \mathrm{kWh}$ are:

$$
\frac{33600}{100 \mathrm{~W} \times 24 \mathrm{~h}}=14 \text { units }
$$

In this case will install 20 units of turbines, the addition of 4 units turbine as a backup power when the 
wind is low intensity and because the spacious of top deck area. Power resulting overall turbines are :

$$
20 \text { Units } \times 100 \mathrm{~W}=2.000 \mathrm{Wh}
$$

The amount of power generated by the turbine in the whole 24 hours is :

$$
2.000 \mathrm{~W} \times 24 \mathrm{~h}=48.000 \mathrm{Wh}=4.8 \mathrm{kWh}
$$

- Initial load of genererator $=80 \mathrm{kVA}$

- After application savonius turbine :

$$
\begin{aligned}
\mathrm{VA} & =80.000-48.000 \\
& =32.000 \mathrm{VA}=3.2 \mathrm{kVA}
\end{aligned}
$$

- $\quad$ Energy savings are done :

$$
\begin{aligned}
& =\frac{\text { Initial Load }- \text { Final Load }}{\text { Initial Load }} \times 100 \% \\
& =\frac{80000-32000}{80000} \times 100 \% \\
& =60 \%
\end{aligned}
$$

So the energy savings obtained amounted to $60 \%$ by using a 20 units turbine savonius.

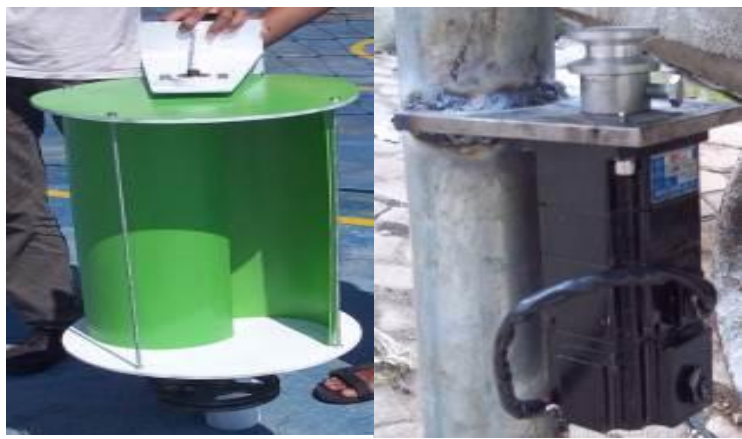

Fig. 7 Savonius turbine \& Generator 200 W

\section{Conclusion}

The most expensive costs to be incurred by the shipping companies is the cost of buying fuel. This is our challenge as an engineer to innovate, because the conduct of research and development for the efficient use of fuel has been done by the engine manufacturer. Therefore now possible is the innovation and development of renewable energy that can be applied in the ship, because the developed countries is currently being in the development and research. Therefore in a position that we can still contend to do the development.

The most important of application renewable energy on the ship is to utilize the energy around the ship, the wind energy available throughout the day, wind energy does not require various forms of procurement and transportation to utilization is does not interfere with the operation of the vessel at the level which is feared. With utilizing existing wind energy throughout the day expected investment costs for turbine installation will be comparable with the results. Development of renewable energy is not to replace the overall function of the auxiliary engine but is still limited to reduce the use of the auxiliary engine.

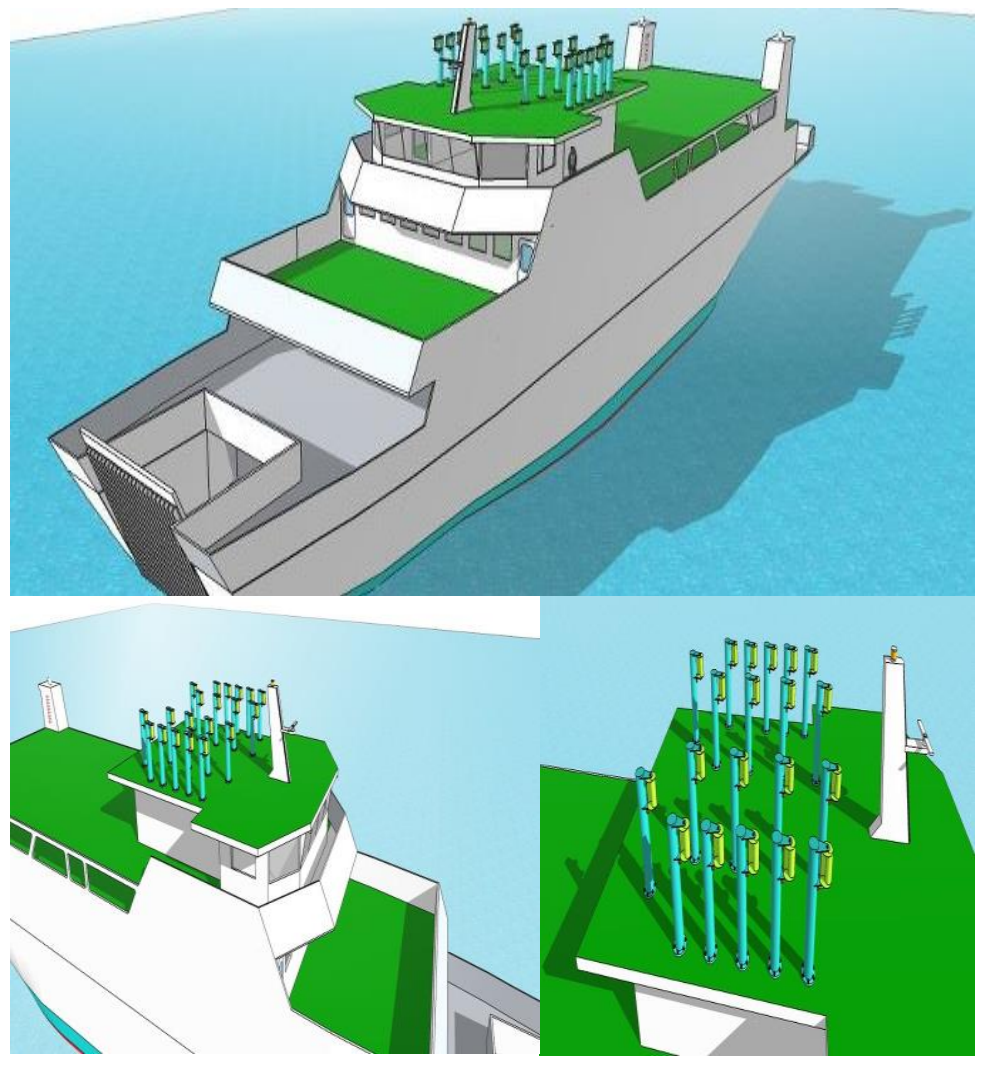

Fig. 8 The Plan of installation in the ships

The reduction of workload will affect to fuel consumption. 
Although the early stages of development of the power generated is not too big than expected. In the future with advances in research and development supporting a variety of devices primarily generators and batteries can produce more power so that it can be reduce the amount of turbine installations, and improve the efficiency of its use.

- Total power requirement of generator $80 \mathrm{kVA}$, about $48 \mathrm{kVA}$ can be supplied by a 20 units turbine which assumed working with half the power, occurred power savings $60 \%$.

- Torque savonius turbine is very small, so that should have to use a special generator that has a small torque and low speed to maximize the power can produced.

- The resulting electric currently is not maximized because the generators are used is not devoted to wind power. With the specialized use of generator for wind power, the electricity generated is expected in accordance with the planning.

- Limited battery power and operation of the plants all day long must be be anticipated if there is excess power generated, if this occurs the plants must be

- turned off and the energy produced is not useful. So had to find how to utilize excess power generated like to other necessities in the ships, fuel cell and hydrogen generator

- Going forward with the modification of the top deck area will be expanded to accommodate more turbines.

- Need to be calculated, short-term and long-term of use savonius turbine in the ship, because the application will be influence the price of ship and also the investment to aplicated savonius turbines is comparable if use fuel.

\section{Acknowledgements}

Authors wish to thank the support and assistance of research funding from the Faculty of Marine Technology, Directorate General of Higher Education (DIKTI) and LP2MK UNSADA. Because the support this research can be accomplished.

\section{References}

Hemami, A. (2011) Wind turbine technolog, USA; Cengage Learning.

Taylor, D.A. (1990) Introduction to marine enginnering; Elsevier butterworth - Heinmann.

Woodyard, D.F. (2009) Pounder's marine diesel engines and gas turbines, Eighth edition; Elsevier butterworth - Heinmann.

Hassan, M. (2011) Design Optimization of Savonius and Wells Turbines. (thesis) Deutch; Otto Von geuricke Universitat magdenburg

Soelaiman, A. (2007) Perancangan, Pembuatan dan Pengujian Prototipe SKEA Menggunakan Rotor Savonius Windshide. (Tugas Akhir) Bandung; Institiut Teknologi Bandung.

Alfin. (2003) Analisa Hasil Rancangan Kincir Angin Model Savonius Untuk Inverter. (Tugas Akhir) Kendari; Universitas haluoleo.

Culph Jr, A.W. (1996) Prinsip-prinsip konversi energi, Jakarta; Erlangga.

Suga, K. (2004) Dasar perencanaan dan pemilihan elemen mesin, Jakarta; Pradnya Paramitha.

Sargolzaeu, J \& Kianifar, A. (2007) Estimaton of the Power Ratio and Torque in Wind Turbine Savonius Rotors Using Artificial Neural. International Journal of Energy, issue2, Vol 1. 